\title{
Reductions in the Prime Stock for Sales Generation in Steel Industry: A Lean Approach using DMAIC Tools
}

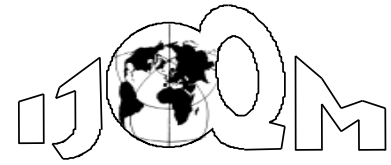

DOI: $10.46970 / 2021.27 .1 .2$

Volume 27, Number 1

March 2021, pp. 23-44

\author{
Saroj Koul \\ OP Jindal Global University \\ (skoul@jgu.edu.in) \\ Pratyush Samantaray \\ Indian Steel Association \\ (pratyushsamantaray@gmail.com) \\ Atul V. \\ SMS India Pvt. Ltd \\ (atulatweb@gmail.com)
}

The purpose is to suggest remedial actions using a DMAIC framework to reduce 'Prime Stock for Sales' (PSFS) in the steel manufacturing process. The specific analysis was conducted for a Plate mill in a steel manufacturing industry in India. It utilizes quality tools like 'Pareto analysis' and 'Fishbone diagram' for organizing data and its subsequent analysis. While the 'Pareto analysis' has identified factor(s) giving the highest impact, the 'Fishbone diagram' has helped to find root causes. Based on the recommendations, if root causes can be discarded from the system, a reduction of the PSFS generation gets delivered. It has been established that Non-Conformance of Order (NCO), Excessive Rolling, and Made to Stock (MTS) are the main factors resulting in over three-fourth of the problem. Several recommendations for corrective actions are also proposed for the reduction of PSFS generation, reinforcing that DMAIC 'Six-sigma' methodology is a practical framework for problem identification, remedial action and implementation. In future, based on a detailed experiment, such root cause analysis can be extended to other parts of the plant and any other steel plant facing a similar challenge.

Keywords: Six-sigma, DMAIC, Ishikawa Fishbone Analysis, Pareto analysis, PSFS, Plate Mill, Case-Study, Steel Industry, India

\section{Introduction}

The second-largest steel producer in the world is India. By 2021 the production capacities are estimated to increase to $128.6 \mathrm{MT}$ from the current position at 106.56 MT. India's finished steel consumption is projected at 230 MT by 2030-31 (IBEF, 2020). However, it is important to monitor the supply and demand in the country. If the demand requirement keeps increasing, producers will have to add capacities, revamp, or increase productivity to meet the market demand. With matching demand and supply, blockage of inventory and Prime Stock for Sales (PSFS) could be avoided. However, PSFS is the result of a demand crisis and poor production planning and quality constraints. Elimination or minimizing of PSFS is always a primary task for any organization. However, some level of PSFS usually is seen in any manufacturing plant, and the organization adopts different methods to bring it below the set levels. 
This case study is about one of India's steel plants manufacturing a wide range of products from long to flat products, which of late has been facing an increase in the PSFS generation of about 5 percent of total production, resulting in financial losses and an increase in total lead-time for customers' demand. This case study uses the 'Fishbone diagram' technique (also well-known as the Ishikawa fishbone diagram or the cause-and-effect diagram) to highlight the causes of generation of PSFS.

The 'Fishbone diagram' is a part of the Seven Quality Tools; it supports identifying and analyzing the root causes of the problems, particularly the quality issues. Invented in the 1960s by Kaoru Ishikawa and represented as a fish skeleton shape, it was first utilized in the quality management process at the Kawasaki Shipyards. The causes in every region are by a drill-down methodology and can be further broken into subcauses for additional investigation (Krajewski et al., 2019) and be helpful in item improvement and investigating cycles. While first applications were in the field of improving managerial issues, it is further utilized widely in different fields, such as, from SME designing (Mazur, 1998), to medication (Frankel et al., 2005); to software engineering (Bjornson et al., 2009), and S\&T Programs (Li and Lee, 2011).

Here, an attempt has been made for exploring and categorizing the root cause. Any technique applying graphical representation or tabulation of data makes the analysis more straightforward for using appropriate management of technology at a steel company. The graphical representation of contributing factors includes Noncompliance of Order (NCO), Excess Rolling, Made-to-Stock (MTS) Projection Plates and Defective Plates. For this purpose, the previous year's Rolling Plan schedule, Weekly PSFS generation schedule, PSFS dispatch schedule and Quality Inspection reports were studied. If appropriately implemented, the proposed plan is likely to ensure a reduction in PSFS generation to half of the current percentage. Since the product and the production process is not unique for this industry, the methodology of this study or even recommendations would be helpful in a similar business facing a similar problem of PSFS.

\section{Literature Review}

Business activities are a combination of plans, conflicts, resolutions, and corrective actions. Since disputes or problems are of the conventional type in most industries, any business's management team applies some standard quality control methods and customizes these to the specific problem to arrive at a solution. 'Six-sigma' is a quality control method that applies a systematic, statistical-based data-driven approach to minimize defects or variations in the process and to attain continual improvement. This process, first developed by Motorola in the year 1980 and promoted by General Electric (GE) in the management process (Neyestani, 2017; Krajewski et al., 2019), is an adopted technology in the industries. According to Kwak and Anbari (2006), the 'Six-sigma' method is specifically a customer-oriented approach. Financial results are generally measured or collected from the reported documents. Further, tools used for advanced data analysis or project management are utilized in the analysis methodology.

Analogous to 'Six-sigma', the method - 'Lean' is a combination of a mindset, philosophy and a set of tools. This popular method is used for streamlining manufacturing and transactional processes (Banga et al., 2020). This method helps in optimizing process flow and eliminating waste. 'Six-sigma' helps remove defects; 
however, 'Lean' helps remove waste since the 'Lean' process also defines values, maps the stream, creates flow, and establishes pull (Giovanni and Cariola, 2020).

'Six-sigma' or 'Lean' or its combination, 'Lean Six-sigma', the application of DMAIC (an acronym for "Define, Measure, Analyse, Improve and Control") improvement cycle, has been identified as a core tool to drive the data-driven projects. By implementing DMAIC at a manufacturing unit, Singh and Singh (2014) have obtained a considerable decrease in quality rejection and substantial net savings per year. Khawar et al. (2016) researched a steel-bar manufacturing plant where production parameters were optimized using DMAIC, resulting in higher productivity and reduced wastage. In the same way, Nourbakhsh et al. (2013) were able to show profitability in the implementation of a six-sigma project determining the amount of 'purchase order' and 'inventory control' at the Khorasan steel plant control.

DMAIC methodologies determine the projects critical to quality characteristics. The first step defines all the apparent causes and then identifies the likely causes that lead to the Source of variation (Smętkowska and Mrugalska, 2018; Nandakumar et al., 2020). Any company can find the most cost-effective way to improve and utilize its resources by reducing defects by applying these methods (Jadhav et al., 2014). The primary tool used in Six-sigma projects is the DMAIC improvement cycle. Once the process's current performance is measured, the goal is to continually improve deviations (Montgomery and Woodall, 2008; Parmar and Desai, 2020).

\subsection{DMAIC ("Define, Measure, Analyse, Improve, Control")}

DMAIC road map has five intermediate targets. These five targets are defined and explained further in this study. Since the concept is inspired by the PDCA cycle, it becomes essential to get feedback in the implementation phase and readjust the measurement. Once the objective is defined, the necessary measure is taken and analyzed while implementing the improvement plant; it may happen that the results are not as expected due to certain missing links during the measurement phase. In case this feedback is captured, the measurement can be adjusted again so that the implementation can be made much more precise further. Five intermediate targets can be understood as below.

Define: In this phase, the team first defines the problem statement and scope of the project. It follows the identification of the resources that are likely to be used at the later stages. The problem statement is derived from the ongoing issues persisting in the whole process and hindering productivity. Based on the devised project plan, a process map is carved out. The team also has to identify the suppliers, inputs and processes required to define the desired output and customers.

Measure: In this phase, the team identifies the area where data collection is necessary, followed by streamlining a plan to collect data and what measurement standards are to be validated to ensure that the collected data is good enough for analysis. After finalizing the data management system, the next step is to collect data relevant to the problem. Data is also to be organized in such a way so that its representation becomes logical, and its usages in analysis tools such as the Control charts or Pareto analysis becomes effortless. 


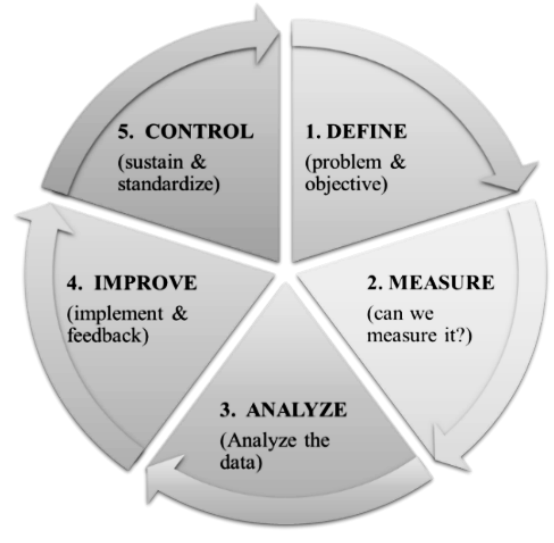

Figure 1 DMAIC Process (author's view)

Analyze: In this phase, data is analyzed using statistical tools and represented to aid visualization and brainstorming. The usual methods used include 'ANOVA' and 'Fishbone diagram' or '6M' (Men, Material, Machine, Method, Measurement, Milieu) (Krajewski et al., 2019). The analysis phase helps identify the root cause by using methodologies such as '5WHY's' for drilling down into a problem and '5HOW's' to develop the details of a solution to a problem. Both are designed to bring clarity and refinement to a problem statement or a potential solution and get to the root cause or root solution.

Improve: In this phase, the results of the analysis are used to plan necessary adjustments to control the deviations. In this phase, the orderly execution of the following three activities takes place.

1) To identify all the probable firsthand solutions.

2) To examine the chances of failure of the proposed solutions, a feasibility-cumviability analysis of the proposed solutions.

3) To validate the solutions statistically, accompanied by launching a pilot project and mapping for implementation.

It is always advisable to implement the solutions on a smaller segment, a pilot project, and once adjusted and standardized, and can then be horizontally deployed in all sections. While validating the solutions, feedback is given to the earlier stage so that measurement and analysis can be modified to enhance later steps of Improve and Control.

Control: In this final phase, the team supports and maintains the solutions implemented in the improvement phase. It is generally achieved by proper documentation, training participants, and implementing 'statistical process control' and creating a 'process monitoring plan'.

\section{Research Methodology}

The research methodology is a problem-solving step. In this case study, the problem is the generation of Prime Stock for Sales (PSFS) in a Plate mill at the steel manufacturing company in Central India. Understanding the steps mentioned under 
DMAIC (section 2.1 above), the first target is to define the problem statement and understand the process flow. Then by following other actions, the final stage of control is reached. The same five steps used in this study are explained below.

\subsection{Definition}

\subsubsection{Prime Stock for Sales (PSFS)}

Any production unit has some standard operating procedure. In an organization, overall production planning involves coordinating the sales department, finance department, production planning and sourcing. After formal approval by the finance ordering the sales department establishes, production planning prepares a systematic plan for the operations. The order specifications are checked first if a similar product is already available in Stock, or new production is planned.

In an ideal situation, to achieve just in time concept, production is planned only after receipt of the order and for the specified quantity. This helps in avoiding inventory blockage. However, such an ideal situation is not available all the time. As a result

- operation department produces even when there is no order,

- $\quad$ while producing for established orders, because of batch size, extra production takes place,

- during operation, functional issues result in the diversion of production to some other specification.

Such extra or additional production is acceptable as part of the production process, and it becomes the responsibility of sales to also look for orders which match the specification of the product already lying in the Stock, such as blocked inventory. There are other reasons also which add to blocked inventory. One major contributor is non-conformities (as per the production order). However, before dispatch and during the inspection, a part of the product does not match the desired/requisite specification. Such non-confirmed products of this order may be the right product for any other order. So, these are left as Stock for possible orders and future dispatch of the plates.

All these additional products are not 'rejects', but Prime product, kept in Stock and the Sales department is on the lookout 'For its Sale'. Hence any such stock is termed as Prime Stock for Sales (PSFS). Since orders and the dispatch of PSFS result in additional work for the sales department and chances of getting similar orders are also less, the target of any organization is to keep this quantity to a bare minimum.

Similarly, for this steel plant, on the one hand, demand raised from marketing via the production planning department decides the type of plates to be produced, while on the other hand, to keep the production equipment operating at threshold level, some production is done for which marketing department has to get proper orders to sell these MTS Plates. PSFS is the generation of plates still lying in the Stock since no matching sales order is available.

While demand raised from marketing department via production planning and control department decides the type of plates to be produced; on the other hand, to keep the production equipment operating at threshold level, some production is done for which marketing department has to get proper orders to sell the MTS Plates. PSFS is the generation of plates that are not the prime or finished product based on the customer's orders (specification and requirement). There are majorly three contributing factors to PSFS, such as: 
- Non-Conformance to Order (NCO) and Defective Plates

- Projection/Made to Stock (MTS) Plates

- Excess Plates (due to slab's minimum order quantity)

Out of these three significant factors, NCO and Defective Plates are generated due to quality issues. Projection/MTS and Excess plates are due to non-quality issues mainly related to Orders (no. of plates). Figure 2 overleaf describes the analysis of PSFS.

General understanding of the problem is like above, where the steel-making process and coordination between marketing and production are to be analyzed.

\subsubsection{Voice of the internal customer (target set by the organization)}

a) The present level of PSFS: Monthly generation of PSFS is approximately 4 percent. When the dispatches are not met, the cumulative number goes up. The actual Figures are to be collected, and the collected data to be identified to place these under different heads.

b) The target level of PSFS: Since the plant production process itself results in a specific generation of PSFS, approximately 2 percent per month seems to be an acceptable level. However, monthly dispatches should be planned in such a way so that the cumulative number remains within this limit.

From (a) \& (b) above, the average PSFS is approximately 4 percent (current level verified by data collection), and the target is to achieve a scale of 2 percent maximum.

\subsubsection{Contributors to PSFS}

a) Steel-making process: As shown in Figure 2, the steel-making process itself contributes to PSFS since the significant cause of deviation in chemical properties initiates at steel making; it is crucial to understand the process flow of steel making. On the flowchart (Figure 3), an attempt has been made to link PSFS to the steel-making process flow. As seen in Figure 3, the steel-making process mainly contributes to the slab's chemical properties, as they are rolled to make a plate. These slabs are then kept in the slab yard for storage or sent to the Plate mill for further rolling to make Plates as per the order's requirement. In case chemical properties are not matching with order specification but are within limits or match other steel grades, these slabs are still rolled at the rolling mill but still result in PSFS.

The Plate mill has a wide variety of plates of thickness ranging from $5 \mathrm{~mm}$ to $150 \mathrm{~mm}$ and width ranging from 1.5 to 5 meters.

b) Plate mill: As shown on the process flow in Figure 4, once plates are rolled and inspection is done, the steel plates are then taken to dispatch Stock as PSFS.

c) Standard operating procedure (SOP) for production planning: As Figure 2 indicates, the degree of coordination between sales and production is also responsible for PSFS; understanding SOP for production planning becomes essential. The explanation is as mentioned below:

- A Sales order upon its booking by the sales department is cleared commercially by the finance department. It then moves into the production planning department, which checks suitable Slabs as per the requirement (of 
the order). The existing slabs are matched as per specifications, then slabs are considered for rolling, and the rolling schedule is planned to make plates. If existing slabs do not match the requirement (of the order), the production planning department makes a casting plan as per the requirement and communicates it to the steel-making team.

- After receiving the casting plan, the slab is cast as per the grade specified in the order, and then the quality of the slab is checked for chemistry, surface quality and dimensions. If the slab's quality is cleared, the slab is sent to the Plate mill slab yard for scheduling for rolling. The Quality control team crosschecks the rolling schedule before giving clearance to Plate mill's Production department. This ensures that the customer's technical specifications match with product characteristics and can include the slab's storage location, the internal and external grade of the finished product, slab dimension, plate dimension as per the order, the customer's requirement in the order, and heat treatment.

- The Rolling schedule, which has information on each slab, is mapped with the sales order, ensuring that each product should pass through the appropriate process route as per the order's required specification. The rolling schedule is provided to the plate mill operation department to produce plates as per the standard operating procedure.

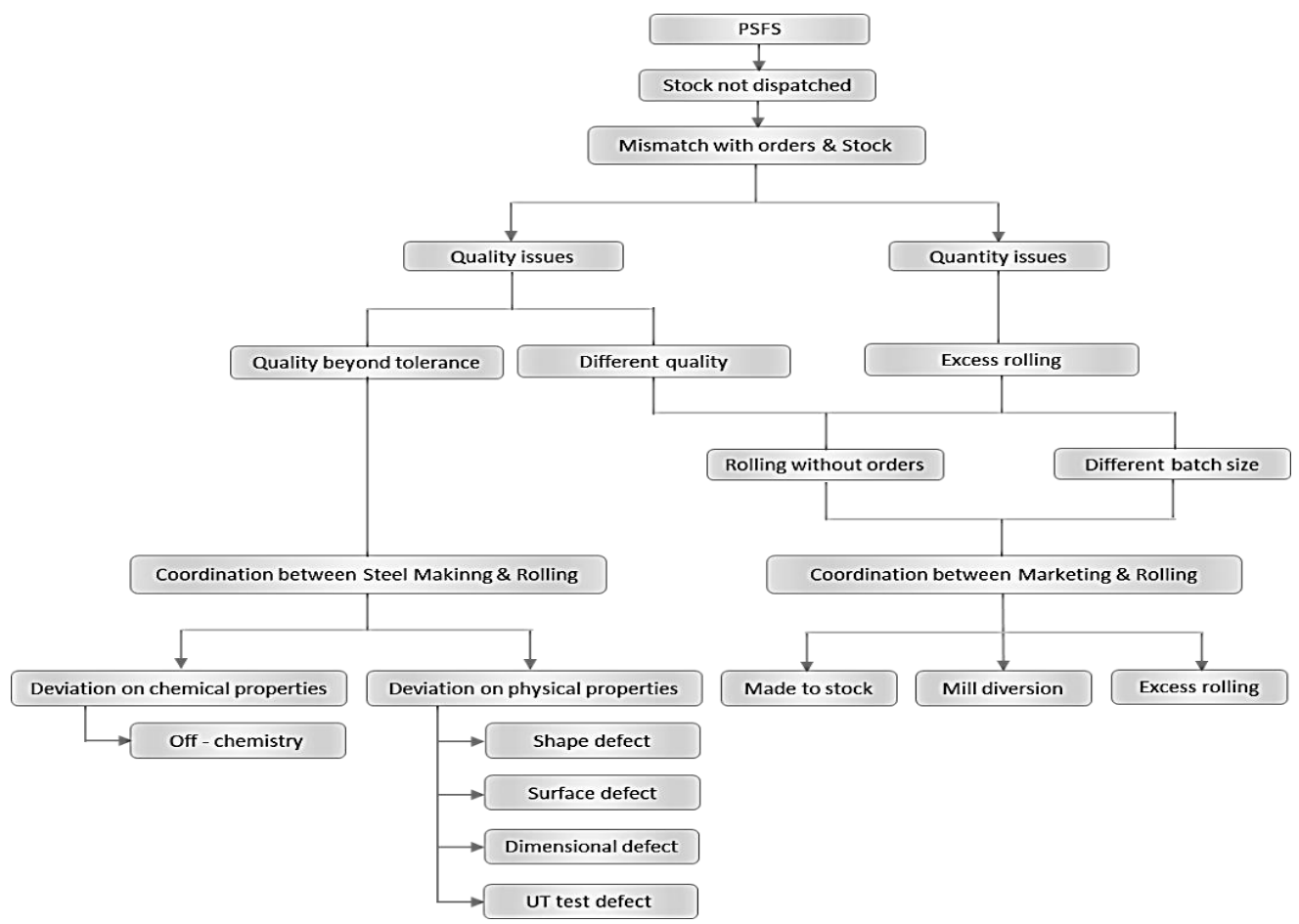

Figure 2: Analysis of PSFS (author's view) 
Once the plate is produced, it goes for the quality check; and if the plate is ready for dispatch, it is termed the prime product or finished product. The plate cannot be dispatched if quality personnel reject it due to any reason, including NCO, Defective, or under quality hold. The NCO plates can be rolled again for another equivalent pending orders. The production planning department plans the rolling after scrutinizing the pending orders.

With further analysis and as represented in Figure 2, it is clear that the steelmaking process and slab casting may result in precise production where chemical properties of the slab become a reason for no /delayed dispatches. Similarly, plate mill operation contributes to the physical properties of plates. In case marketing and production planning are not advanced enough, sometimes plate mill and caster have to produce some general grades of steel and declare the same as MTS, lying in the stockyard for an extended period in the form of PSFS. The three significant factors leading to PSFS are a) Quality beyond tolerance, b) Different quality, and c) additional Rolling.

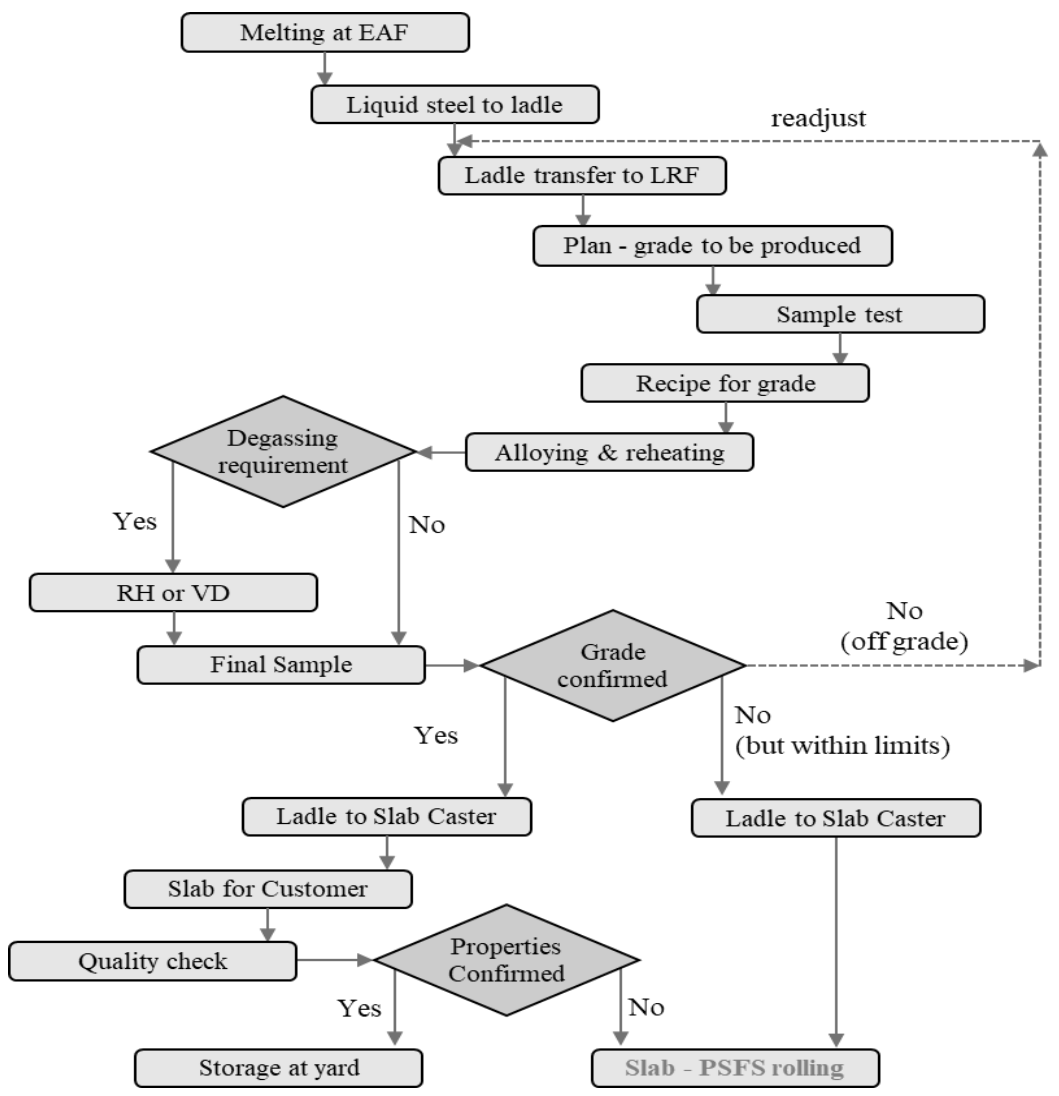

Figure 3: Steel-making Process Flow \& PSFS (author's view) 


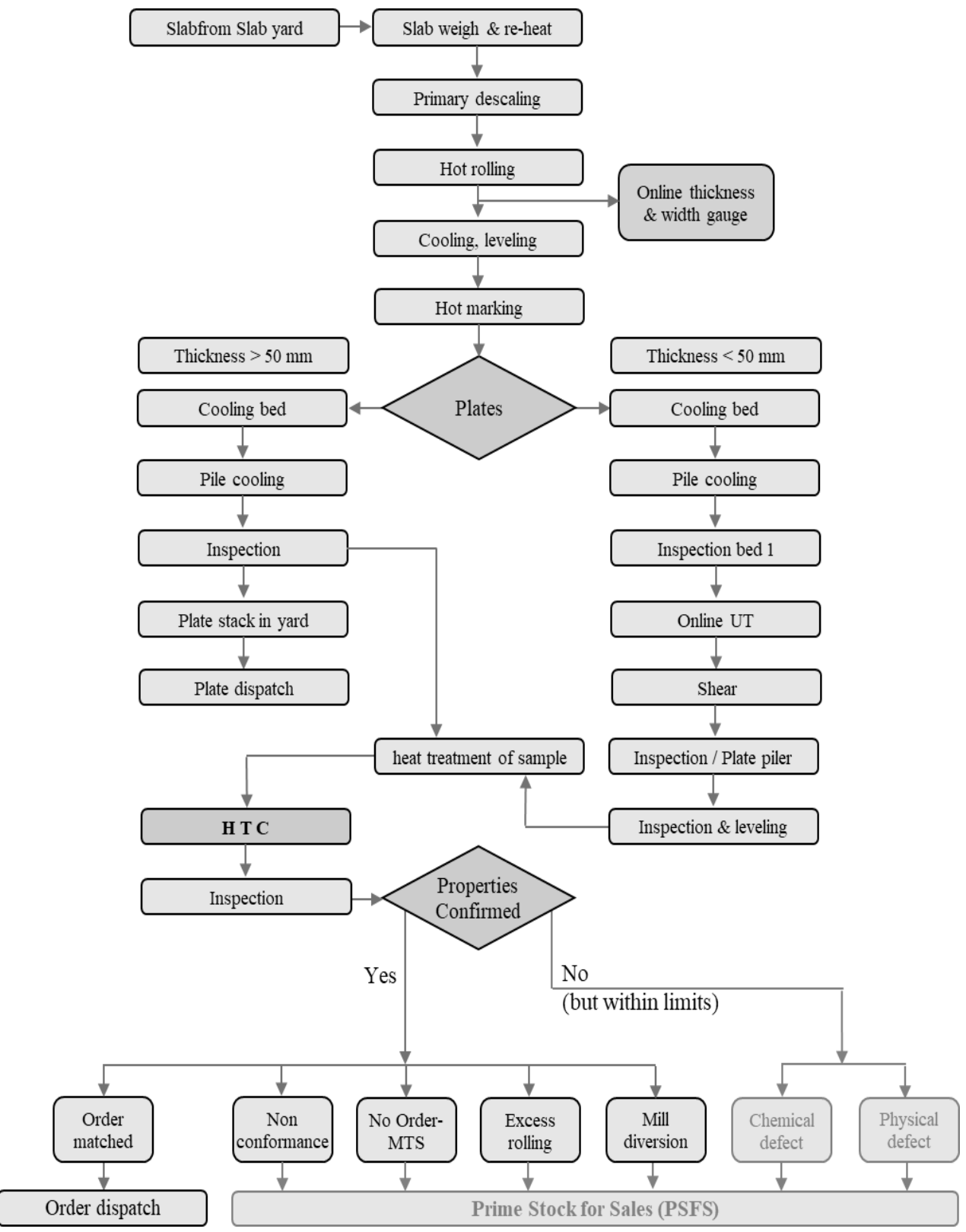

Figure 4: Plate mill Process Flow and PSFS (author's view)

\subsection{Measure}

Having understood PSFS and its factors, this section attempts to collect the relevant data from different stages and later analyze it. 
Table 1: PSFS - last six months

\begin{tabular}{|c|c|c|}
\hline SI No & Reasons for PSFS & PSFS (t) \\
\hline 1 & Bow & 77 \\
\hline 2 & Buckling & 3 \\
\hline 3 & Head and tail up & 192 \\
\hline 4 & Levelling not working & 4 \\
\hline 5 & Waviness in Shape & 21 \\
\hline 6 & Burr & 1,520 \\
\hline 7 & Crack & 5,992 \\
\hline 8 & Dent & 546 \\
\hline 9 & Mark & 80 \\
\hline 10 & Roll mark & 3 \\
\hline 11 & Rolled on foreign material & 36 \\
\hline 12 & Scab & 188 \\
\hline 13 & Scale formation & 6 \\
\hline 14 & Sliver & 531 \\
\hline 15 & Surface burst & 4 \\
\hline 16 & Camber & 412 \\
\hline 17 & Cut mark & 21 \\
\hline 18 & Damage & 12 \\
\hline 19 & Edge bend & 130 \\
\hline 20 & Edge burst & 138 \\
\hline 21 & Edge damage & 92 \\
\hline 22 & Length & 804 \\
\hline 23 & Thickness & 160 \\
\hline 24 & Width & 310 \\
\hline 25 & Wrong cut & 6 \\
\hline 26 & Lamination & 30 \\
\hline 27 & Ultrasonic tests (UT) failure & 829 \\
\hline 28 & Off chemistry & 30 \\
\hline 29 & Wrong planning & 284 \\
\hline 30 & MTS & 4,439 \\
\hline 31 & Mill diversion & 1,110 \\
\hline 32 & Excess Rolling & 8,589 \\
\hline 33 & Chemical defect & 2,773 \\
\hline 34 & Physical defect & 2,241 \\
\hline \multirow[t]{3}{*}{35} & Order short closed & 94 \\
\hline & Total PSFS & 31,704 \\
\hline & Total Production & 537,364 \\
\hline
\end{tabular}


The respective flow charts, as indicated in Figure 2, 3, \& 4, explain the factors that can lead to PSFS. Requisite data was collected from the ERP system at the steel plant. The daily report of quality inspection for the last year was scrutinized to find the percentage of NCO and Defective Plates. Further, to identify the root causes of the process, the process flows of the Slab caster and the Plate mill rolling sequence were examined with the steel plant's respective operations team.

While the standard operating procedure provided order planning, the sales and marketing department's functioning indicated a synchronization between sales, production planning and control, and the marketing department. Departments helped in collecting data, and the same is at Table 1.

During the six months period, the total quantity of PSFS stands at $31,704 \mathrm{t}$, with the entire production from the plate mill recorded as 537,364 t. The steel plant uses all these 35 reasons (terms) for PSFS as a standard to identify the reasons because of which a particular product/plate is lying as part of PSFS.

\subsection{Analyze}

Since the organizational target is to bring down the average PSFS from the current 4 percent per month to below 2 percent; for analysis of collected data, it becomes essential to verify the PSFS levels. Hence, the data collected as per Table 1 was analyzed further to identify 'What is the percentage of PSFS in the last six months?' It was executed by categorizing the data on significant heads and then using a 'Pareto chart' to identifying the primary cause.

Data analysis indicates that the percentage of PSFS in the six months is 5.90 percent (not 4 percent as expected by the steel plant team). The analysis (Table 2) also helps in classifying the leading factors under seven main causes for PSFS.

1) NCO: When the specification as demanded in the order does not match with rolled plates' specification,

2) Excess rolling: Chemical and physical properties are as per standards but no fresh order for these small quantities and rolled due to batch size,

3) MTS: Chemical and physical properties are as per standards, but no fresh customer order for such specifications leading to high inventory carrying cost,

4) Chemical defect: Chemical properties are not as per standards,

5) Physical defect: Physical properties are not as per standards,

6) Mill Diversion: When some rolling is going on, and due to specific operational reasons, some different rolling is planned,

7) Order short closed: Dispatched quantity is a little lower than the rolled quantity. 
Table 2: PSFS - six months - Data Analysis

\begin{tabular}{|c|c|c|c|c|c|c|c|c|}
\hline $\begin{array}{l}\text { Sl. } \\
\text { No }\end{array}$ & Reasons & $\begin{array}{c}\text { PSFS } \\
\text { (t) }\end{array}$ & Causes & $\begin{array}{c}\text { PSFS } \\
(\mathbf{t})\end{array}$ & $\begin{array}{c}\text { Cause } \\
\text { classification }\end{array}$ & $\begin{array}{c}\text { PSFS } \\
(\mathbf{t})\end{array}$ & $\begin{array}{l}\text { Percent } \\
\text { of total } \\
\text { PSFS }\end{array}$ & $\begin{array}{c}\text { Percent of } \\
\text { total } \\
\text { Production }\end{array}$ \\
\hline 1 & Bow & 77 & \multirow{5}{*}{$\begin{array}{l}\text { Shape } \\
\text { defect }\end{array}$} & \multirow{5}{*}{297} & \multirow{29}{*}{$\begin{array}{l}\text { Non- } \\
\text { Conformance } \\
\text { of Order }\end{array}$} & \multirow{29}{*}{12,460} & \multirow{29}{*}{$39.30 \%$} & \multirow{29}{*}{$2.32 \%$} \\
\hline 2 & Buckling & 3 & & & & & & \\
\hline 3 & Head and tail up & 192 & & & & & & \\
\hline 4 & $\begin{array}{l}\text { Levelling not } \\
\text { working }\end{array}$ & 4 & & & & & & \\
\hline 5 & Waviness in Shape & 21 & & & & & & \\
\hline 6 & Burr & 1,520 & \multirow{10}{*}{$\begin{array}{l}\text { Surface } \\
\text { defect }\end{array}$} & \multirow{10}{*}{8,907} & & & & \\
\hline 7 & Crack & 5,992 & & & & & & \\
\hline 8 & Dent & 546 & & & & & & \\
\hline 9 & Mark & 80 & & & & & & \\
\hline 10 & Roll mark & 3 & & & & & & \\
\hline 11 & Rolled on pit & 36 & & & & & & \\
\hline 12 & Scab & 188 & & & & & & \\
\hline 13 & Scale formation & 6 & & & & & & \\
\hline 14 & Sliver & 531 & & & & & & \\
\hline 15 & Surface burst & 4 & & & & & & \\
\hline 16 & Camber & 412 & \multirow{10}{*}{$\begin{array}{l}\text { Dimensio } \\
\text { nal defect }\end{array}$} & \multirow{10}{*}{2,083} & & & & \\
\hline 17 & Cut mark & 21 & & & & & & \\
\hline 18 & Damage & 12 & & & & & & \\
\hline 19 & Edge bend & 130 & & & & & & \\
\hline 20 & Edge burst & 138 & & & & & & \\
\hline 21 & Edge damage & 92 & & & & & & \\
\hline 22 & Length & 804 & & & & & & \\
\hline 23 & Thickness & 160 & & & & & & \\
\hline 24 & Width & 310 & & & & & & \\
\hline 25 & Wrong cut & 6 & & & & & & \\
\hline 26 & Lamination & 30 & \multirow{2}{*}{ UT failure } & \multirow{2}{*}{859} & & & & \\
\hline 27 & UT failure & 829 & & & & & & \\
\hline 28 & Off chemistry & 30 & $\begin{array}{l}\text { Off } \\
\text { chemistry }\end{array}$ & 30 & & & & \\
\hline 29 & Wrong planning & 284 & $\begin{array}{l}\text { Wrong } \\
\text { planning }\end{array}$ & 284 & & & & \\
\hline 30 & $\begin{array}{l}\text { Made-to-stock } \\
\text { (MTS) }\end{array}$ & 4,439 & $\begin{array}{l}\text { Made-to- } \\
\text { stock } \\
\text { (MTS }\end{array}$ & \multirow[t]{2}{*}{5,549} & $\begin{array}{l}\text { Made-to- } \\
\text { stock MTS) }\end{array}$ & 4,439 & $14.00 \%$ & $0.83 \%$ \\
\hline 31 & Mill diversion & 1,110 & $\begin{array}{l}\text { Mill } \\
\text { diversion }\end{array}$ & & Mill diversion & 1,110 & $3.50 \%$ & $0.21 \%$ \\
\hline 32 & Excess Rolling & 8,589 & $\begin{array}{l}\text { Excess } \\
\text { Rolling } \\
\end{array}$ & 8,589 & Excess rolling & 8,589 & $27.09 \%$ & $1.60 \%$ \\
\hline 33 & Chemical defect & 2,773 & $\begin{array}{l}\text { Chemical } \\
\text { defect }\end{array}$ & \multirow{2}{*}{5,014} & $\begin{array}{l}\text { Chemical } \\
\text { defect }\end{array}$ & 2,773 & $8.75 \%$ & $0.52 \%$ \\
\hline 34 & Physical defect & 2,241 & $\begin{array}{l}\text { Physical } \\
\text { defect }\end{array}$ & & $\begin{array}{l}\text { Physical } \\
\text { defect }\end{array}$ & 2,241 & $7.07 \%$ & $0.42 \%$ \\
\hline \multirow[t]{3}{*}{35} & Order short closed & 94 & $\begin{array}{l}\text { Order } \\
\text { short } \\
\text { closed }\end{array}$ & 94 & $\begin{array}{l}\text { Order short } \\
\text { closed }\end{array}$ & 94 & $0.29 \%$ & $0.02 \%$ \\
\hline & Total PSFS & 31,704 & & 31,704 & & 31,704 & $100 \%$ & $5.90 \%$ \\
\hline & Total Production & 537,364 & & 537,364 & & 537,364 & & \\
\hline
\end{tabular}


The summary of the data is in Table 3 .

Table 3: PSFS - summary quantity and percentage - causes

\begin{tabular}{|c|l|c|c|c|}
\hline S1. No. & Cause classification & $\begin{array}{c}\text { PSFS quantity } \\
\text { (t) }\end{array}$ & $\begin{array}{c}\text { PSFS cause } \\
\text { percentage }\end{array}$ & $\begin{array}{c}\text { PSFS percentage } \\
\text { of production }\end{array}$ \\
\hline 1 & NCO & 12,460 & $39.30 \%$ & $2.32 \%$ \\
\hline 2 & Excess Rolling & 8,589 & $27.09 \%$ & $1.60 \%$ \\
\hline 3 & MTS & 4,439 & $14.00 \%$ & $0.83 \%$ \\
\hline 4 & Chemical defect & 2,773 & $8.75 \%$ & $0.52 \%$ \\
\hline 5 & Physical defect & 2,241 & $7.07 \%$ & $0.42 \%$ \\
\hline 6 & Mill diversion & 1,110 & $3.50 \%$ & $0.21 \%$ \\
\hline 7 & Order short closed & 94 & $0.29 \%$ & $0.02 \%$ \\
\hline & Total PSFS & 31,704 & & \\
\hline & Total production & $\mathbf{5 3 7 , 3 6 4}$ & & \\
\hline
\end{tabular}

Data is further analyzed using a 'Pareto Chart' to understand the severity of the causes.

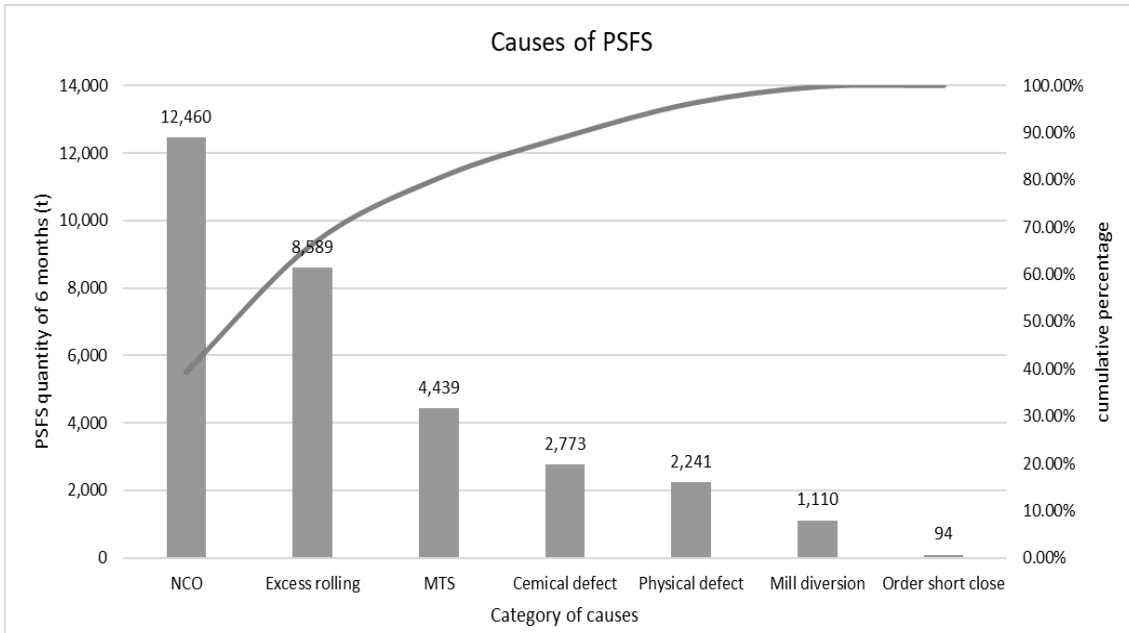

Figure 5: Pareto Chart

From the Pareto analysis in Figure 5, it can be concluded that generation of 80 percent PSFS is due mainly to NCO Plates (contribution at 39.30 percent), followed by excess rolled plates (27.09 percent) and MTS (14.00 percent).

\section{Root Cause Analysis}

The Ishikawa fishbone diagram shows probable prospects for identifying bottlenecks and increasing production in the steel industry. Problems causing the most delay were in the production process while other problems such as shift changeover, less 
skilled/insufficient workers and communication gap could be sorted out right away (Vaishya and Baraiya, 2016).

Tegegne and Singh (2013) have used the Ishikawa diagram to analyze the root causes and have found plausible solutions behind surface imperfections in the projecting cycle for assembling parts, both for vast and trim parts. Gandhi et al. (2016) utilized the Ishikawa fishbone diagram to classify possible causes and outline the degrees of causation for bearings, a fundamental workpiece in hardware gadgets. The steel ball's surface nature is the principal factor that influences the bearing's accuracy and life span.

For root cause analysis of PSFS generation, the application of the Ishikawa fishbone diagram is considered. Here, all the seven leading causes are evaluated for reasons so that corrective actions can be planned to minimize or eliminate them. While discussing with the operation and maintenance team, these causes were listed and linked (Figure $6 \mathrm{a}, \mathrm{b}, \mathrm{c}$ and d). Since causes are known (Annexure 1), their present status is also known, and hence during the control phase, corrective actions can be planned.

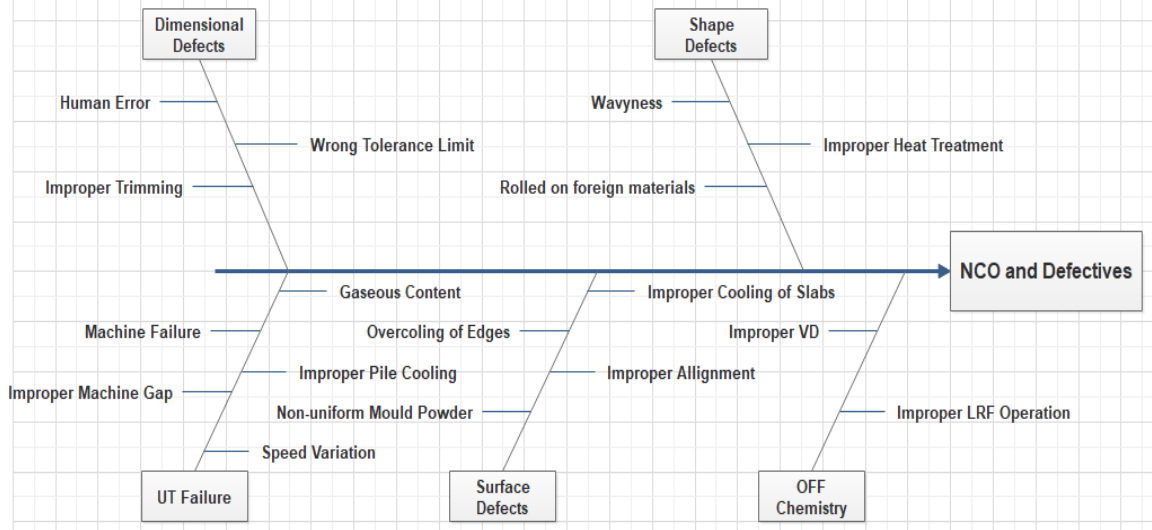

Figure 6 a: Fishbone diagram (NCO and Defectives as the leading causes) [Source: based on Annexure 1]

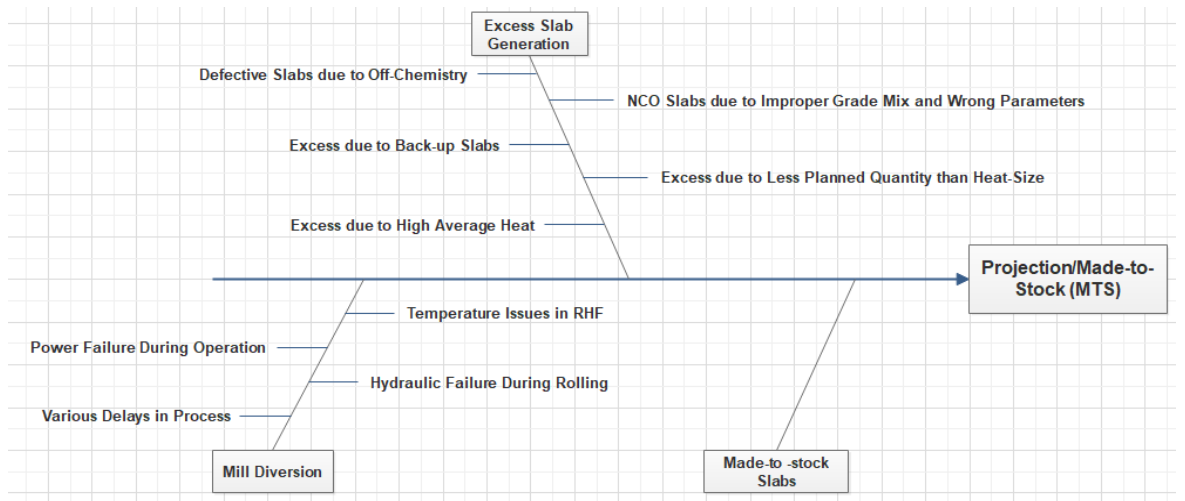

Figure 6 b: Fishbone diagram (Projection/MTS as the leading cause) [Source: based on Annexure 1] 


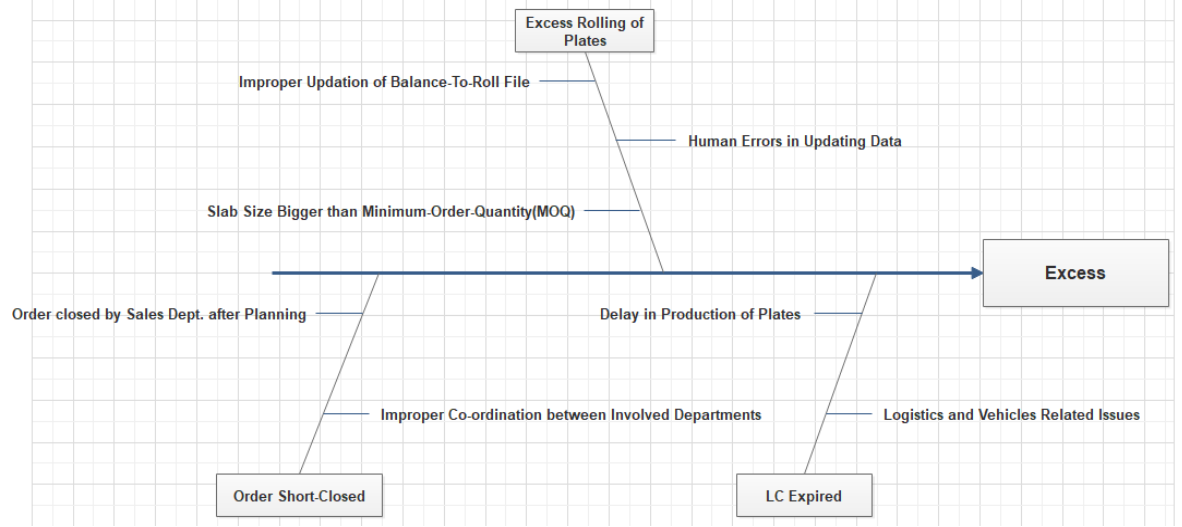

Figure 6 c: Fishbone diagram (Excess rolling as a leading cause) [Source: based on Annexure 1]

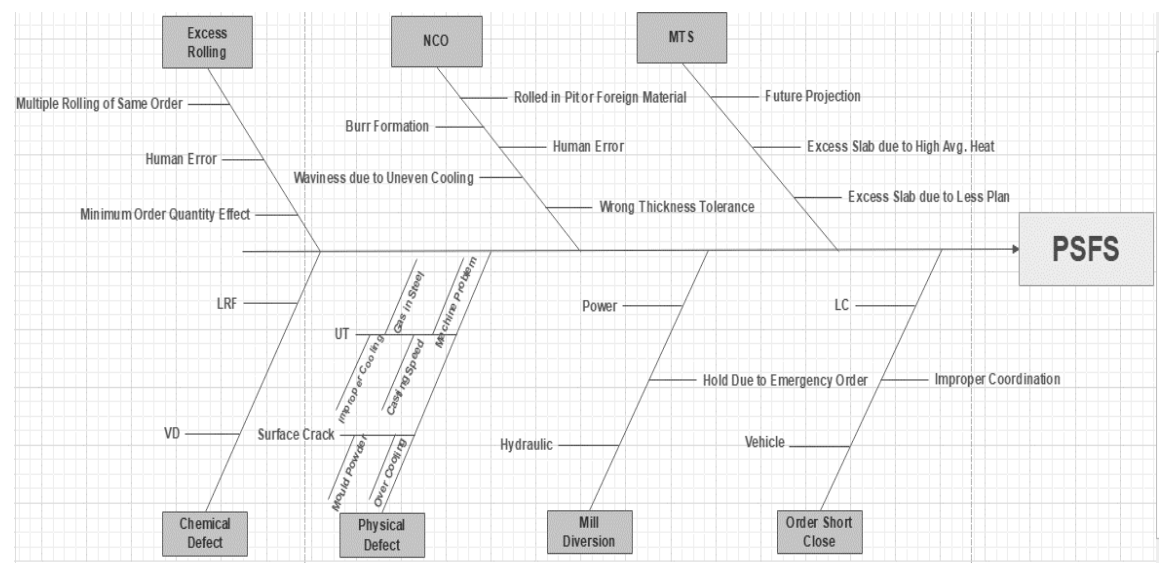

Figure 6 d: Fishbone diagram (showing the linked seven leading causes)

\subsection{Improve}

After finding out all possible root causes, and after going through the overall process of plate production, SOP of production planning, product dispatch, sales and marketing of plates, the proposed recommendations are detailed in Annexure 1.

Referring to the results of Pareto analysis, generation of 80 percent of PSFS is primarily due to NCO Plates (contribution at 39.30 percent), followed by excess rolled plates (27.09 percent), and MTS (14.00 percent). Hence, primary emphasis is to be given to these three cause classifications. 
NCO Plates: As extracted from Table 2 and recommended in Annexure 1, the main reasons for NCO Plates are Cracks, Burrs, UT, Length and Width.

- Cracks are generated during the casting process at Slab Caster. Improved maintenance on the slab casting machine and monitoring of water spray nozzles will help maintain uniform cooling during the casting process. If necessary, preventive maintenance schedule and cooling parameters are to be revisited to achieve the results.

- Burr on the rolled plates is the result of the rolling process at the plate mill. These are generated when there is a temperature difference on the two sides of the plate during rolling. Prevention of any such condition requires adherence to SOP for maintaining temperature uniformity on the plate during rolling.

- Gaseous contents in steel slab, machine failure during casting, roll gap, variation in casting speed and pile cooling procedure are parameters that may result in nonconformities in UT failure. A review of these under SOP can quickly help in eliminating UT failures.

- Length and width are dimensions based on fed setpoints governing the rolling process. When these setpoints are fed manually, human errors are the leading cause of variation in length and width. Either a cross verification of fed setpoints is necessary, or the next level of automation system will be helpful.

Excess Rolled Plates: Human error and multiple rolling for the same order can be avoided by eliminating manual working by employing software packages, such as "Manufacturing Execution System" or production planning control under industry 4.0. When order quantity is too low, production planning can look for appropriate slab size or accumulate several such orders to minimize excess rolling.

MTS: Since slab caster and rolling mill have to maintain certain production levels, it becomes a prime responsibility of the marketing team to keep sufficient orders to avoid MTS.

In most cases, these are revision and adherence to SOP only.

\subsection{Control-Phase - Implementation}

In this final phase, recommendations have to be implemented, if and as feasible. So, the proposed recommendations are given to the respective departments to consider the viable and essential points to achieve in the system to reduce the generation of PSFS. Since significant recommendations are related to the revision of SOP, these can be prioritized. Updated SOP and its implementation will help achieve process improvements by the Plate mill, Slab caster, and Ladle Refining Furnace (LRF) (refer to Figure 3) operation and maintenance teams.

Hence, implementation can be taken up for 1) updating SOPs, 2) implementing updated SOPs (maintenance scheduling, operational parameters, control setpoints), 3) implementing the next level of automation, and 4) implementing control software packages (Manufacturing Execution System (MES); industry 4.0). Implementation of MES in the production planning of plate mill shall ensure an error-free process. Even industry 4.0 and digitalization provides several similar options for adopting a process control model. 


\section{Conclusions}

This case study at a steel plant was studied to reduce its Prime Stock for Sales (PSFS). Currently, at this plant, the monthly PSFS percentage is 4 percent of the total plate production. By implementing the suggested recommendation, a significant reduction of the PSFS generation is possible. The main recommendation identified was for NCO, Excessive Rolling and MTS. After utilizing the 'Pareto analysis' and 'Fishbone diagram,' these were identified as the main factors resulting in over three-fourth of the problem. Overall data collection, analysis, and recommendations for implementation were framed under the DMAIC 'Six-sigma' methodology. In future, based on a detailed experiment, such root cause analysis can be extended to other parts of the plant and any other steel plant facing a similar challenge.

\section{Acknowledgement}

The authors appreciate and thank the executives and administrators of the steel plant for the visits and discussions from January 2020 to December 2020. The authors thank the anonymous reviewers for their valued propositions that have made the paper more systematic and instructive.

\section{References}

1. Banga, H. K., Kumar, R., Kumar, P., Purohit, A., Kumar, H., \& Singh, K. (2020). Productivity improvement in manufacturing industry by lean tool. Materials Today: Proceedings, 28, 1788-1794.

2. Bjornson, F. O., Wang, A. I., \& Arisholm, E. (2009). Improving the effectiveness of root cause analysis in post mortem analysis: A controlled experiment. Information and Software Technology, 51(1), 150-161.

3. De Giovanni, P., \& Cariola, A. (2020). Process innovation through industry 4.0 technologies, lean practices and green supply chains. Research in Transportation Economics, 100869.

4. Frankel, H. L., Crede, W. B., Topal, J. E., Roumanis, S. A., Devlin, M. W., \& Foley, A. B. (2005). Use of corporate Six Sigma performance-improvement strategies to reduce incidence of catheter-related bloodstream infections in a surgical ICU. Journal of the American College of Surgeons, 201(3), 349-358.

5. Gandhi, C.A., Vijaykumar K.N., and Crasta, F., (2016) Improving Quality Parameters of Steel Balls Affecting Noise in Ball Bearing, International Research Journal of Engineering and Technology, 3(6), 2297-2306. https://www.irjet.net/archives/V3/i6/IRJET-V3I6420.pdf

6. IBEF, (2020) https://www.ibef.org/industry/steel-presentation, accessed March 28, 2021.

7. Ishikawa, K1976. Guide to Quality Control. Tokyo, Japan: Asian Productivity Organization.

8. Jadhav, SB, Jadhav, GP, and Teli, SN (2014) Steel Industries and Six Sigma, Int' 1 Journal of Scientific \& Engineering Research, 5(12): 53-59.

9. Krajewski Lee. J., Ritzman Larry. P., Malhotra Manoj. K. \& Srivastava, Samir. K (2019). Operations Management. Pearson Education. 
10. Naeem, K., Ullah, M., Tariq, A., Maqsood, S., Akhtar, R., Nawaz, R., \& Hussain, I. (2016). Optimization of steel bar manufacturing process using six sigma. Chinese Journal of Mechanical Engineering, 29(2), 332-341.

11. Kwak, Y. H., \& Anbari, F. T. (2006). Benefits, obstacles, and future of six sigma approach. Technovation, 26(5-6), 708-715.

12. Li, S. S., \& Lee, L. C. (2011). Using fishbone analysis to improve the quality of proposals for science and technology programs. Research Evaluation, 20(4), 275282.

13. Montgomery, D. C., \& Woodall, W. H. (2008). An overview of six sigma. International Statistical Review/Revue Internationale de Statistique, 329-346.

14. Mazur, G. H. (1998, August). Strategy deployment for small and medium enterprises. In Proceedings of the International Symposium on Quality Function Deployment. Sydney.

15. Nandakumar, N., Saleeshya, P. G., \& Harikumar, P. (2020). Bottleneck Identification and Process Improvement By Lean Six Sigma DMAIC Methodology. Materials Today: Proceedings, 24, 1217-1224.

16. Nourbakhsh K., Ali Z., Shah I., \& Ghaffari S., (2013) Investigating the influence of Six Sigma Implementation in Khorasan Steel plant in 2011, Research J of Applied Sciences, Engineering and Technology, 6 (13): 2296-2300.

17. Neyestani, B. (2017). Seven basic tools of quality control: The appropriate techniques for solving quality problems in the organizations. Available at SSRN 2955721.

18. Parmar, P. S., \& Desai, T. N. (2020). Evaluating Sustainable Lean Six Sigma enablers using fuzzy DEMATEL: A case of an Indian manufacturing organization. Journal of Cleaner Production, 265, 121802.

19. Singh, J., \& Singh, H. (2014). Performance enhancement of manufacturing unit using Six Sigma DMAIC approach: a case study. In Proceedings of the International Conference on Research and Innovations in Mechanical Engineering (pp. 563-571). Springer, New Delhi.

20. Smętkowska, M., \& Mrugalska, B. (2018). Using Six Sigma DMAIC to improve the quality of the production process: a case study. Procedia-Social and Behavioral Sciences, 238, 590-596.

21. Tegegne, A., \& Singh, A. P. (2013). Experimental Analysis And Ishikawa Diagram For Burn On Effect On Manganese Silicon Alloy Medium Carbon Steel Shaft. International Journal for quality research, 7(4).

22. Vaishya, A.1., and Baraiya, R., (2016) Identifying the Bottlenecks \& Increasing the Production of Finishing Area in a Steel Manufacturing Process Industry-A Case Study, International Journal of Engineering Sciences \& Research Technology, 5(4): 1-7. 


\section{Annexure 1}

\begin{tabular}{|c|c|c|}
\hline $\begin{array}{l}\text { CAUSES: UT } \\
\text { FAILURE }\end{array}$ & CURRENT PRACTICE & RECOMMENDED PRACTICE \\
\hline \multirow[t]{3}{*}{$\begin{array}{l}\text { Gaseous } \\
\text { content in steel }\end{array}$} & $\begin{array}{l}\text { Improper Vacuum De-gassing operation } \\
\text { forms gaseous content in steel }\end{array}$ & $\begin{array}{l}\text { In Vacuum De-Gassing Process, the hot material } \\
\text { should be held for a minimum of } 16 \text { minutes with } \\
\text { vacuum pressure not exceeding two (2) mbar }\end{array}$ \\
\hline & $\begin{array}{l}\text { Open casted slabs may have gaseous } \\
\text { content. Plates out of this type of slab will } \\
\text { fail in Ultrasonic Testing. }\end{array}$ & $\begin{array}{l}\text { The open casted slab should be rolled for non-UT } \\
\text { ordered plates. PPC should check those slabs } \\
\text { before rolling them into plates }\end{array}$ \\
\hline & $\begin{array}{l}\text { Sometimes non-VD slabs go for } \\
\text { Ultrasonic testing. }\end{array}$ & $\begin{array}{l}\text { Before rolling, PPC and plate mill process should } \\
\text { ensure that non-VD slabs should not go for } \\
\text { Ultrasonic testing }\end{array}$ \\
\hline \multirow{2}{*}{$\begin{array}{l}\text { Machine } \\
\text { Failure at any } \\
\text { stage of the } \\
\text { process }\end{array}$} & $\begin{array}{l}\text { Improvement required in the } \\
\text { maintenance of the machines involved in } \\
\text { the casting process }\end{array}$ & $\begin{array}{l}\text { TPM should be implemented, and all FUGAIs } \\
\text { related to the process should be identified and } \\
\text { rectified }\end{array}$ \\
\hline & $\begin{array}{l}\text { Power failure in between the casting } \\
\text { process }\end{array}$ & $\begin{array}{l}\text { UPS Supply should be available for critical } \\
\text { equipment. The process team should identify the } \\
\text { equipment's critical for the process. }\end{array}$ \\
\hline $\begin{array}{l}\text { Improper Pile } \\
\text { Cooling }\end{array}$ & $\begin{array}{l}\text { Slabs are stacked in the open area, and } \\
\text { pile cooling is done in an open area. That } \\
\text { may lead to the ingression of moisture } \\
\text { into the steel }\end{array}$ & $\begin{array}{l}\text { Pile cooling can be done using box cooling or } \\
\text { underground cooling }\end{array}$ \\
\hline \multirow{2}{*}{$\begin{array}{l}\text { Improper } \\
\text { Machine Gaps } \\
\text { at different } \\
\text { segments }\end{array}$} & Improper frequency of Gap checking. & $\begin{array}{l}\text { For each thickness change, Gap checking of the } \\
\text { segments should be done before casting. }\end{array}$ \\
\hline & $\begin{array}{l}\text { Availability of one gap checker } \\
\text { (VATRON), which may malfunction at } \\
\text { times }\end{array}$ & $\begin{array}{l}\text { One spare gap checker (VATRON) should be } \\
\text { maintained for contingency. }\end{array}$ \\
\hline Casting Speed & Variation in Casting Speed & $\begin{array}{l}\text { Casting speed to be maintained for a specific } \\
\text { width by maintaining the superheat temperature } \\
\text { as per casting speed 'vs' superheat temperature } \\
\text { chart. }\end{array}$ \\
\hline
\end{tabular}

\begin{tabular}{|c|c|c|}
\hline $\begin{array}{l}\text { CAUSES: SURFACE } \\
\text { CRACK }\end{array}$ & CURRENT PRACTICE & RECOMMENDED PRACTICE \\
\hline $\begin{array}{l}\text { Improper Cooling of Slab } \\
\text { due to clogging in any water } \\
\text { spray nozzles }\end{array}$ & $\begin{array}{l}\text { There is no proper schedule for } \\
\text { maintenance of the water spray- } \\
\text { nozzles }\end{array}$ & $\begin{array}{l}\text { Scheduled maintenance to be done } \\
\text { during an ideal time by taking the } \\
\text { operation team in line. } \\
\text { The function of Nozzles to be } \\
\text { checked before each casting. }\end{array}$ \\
\hline Over cooling of Edges & $\begin{array}{l}\text { More water spray on the edge of slabs } \\
\text { than other areas. }\end{array}$ & $\begin{array}{l}\text { The caster operation team has to } \\
\text { ensure uniform cooling during the } \\
\text { process. }\end{array}$ \\
\hline $\begin{array}{l}\text { Improper Segment } \\
\text { Alignment }\end{array}$ & $\begin{array}{l}\text { Uneven alignment in the bottom part } \\
\text { of the segment causes a bend in the } \\
\text { surface of the slabs. }\end{array}$ & $\begin{array}{l}\text { Maintenance team to take care of } \\
\text { the alignment (bottom part of the } \\
\text { segment) }\end{array}$ \\
\hline $\begin{array}{l}\text { Non-uniformity of mould- } \\
\text { powder use for lubrication }\end{array}$ & $\begin{array}{l}\text { Different varieties of mould-powders } \\
\text { are used for different grades, and non- } \\
\text { uniformity is occurring due to } \\
\text { powders' chemistry variation. }\end{array}$ & $\begin{array}{l}\text { By using standard quality of } \\
\text { mould-powder and discarding the } \\
\text { use of a variety of sub-standard } \\
\text { mold powders }\end{array}$ \\
\hline
\end{tabular}




\begin{tabular}{|l|l|l|}
\hline \multicolumn{1}{|c|}{$\begin{array}{c}\text { CAUSES: OFF- } \\
\text { CHEMISTRY }\end{array}$} & CURRENT PRACTICE & RECOMMENDED PRACTICE \\
\hline $\begin{array}{l}\text { Improper VD } \\
\text { Operation }\end{array}$ & $\begin{array}{l}\text { Improper Vacuum De-gassing operation } \\
\text { forms gaseous content in steel }\end{array}$ & $\begin{array}{l}\text { In Vacuum De-Gassing Process, the hot } \\
\text { material should be held for a minimum } \\
\text { of } 16 \text { minutes with vacuum pressure not } \\
\text { exceeding two (2) mbar. }\end{array}$ \\
\hline $\begin{array}{l}\text { Improper LRF } \\
\text { operation during } \\
\text { Ferro-alloy addition }\end{array}$ & $\begin{array}{l}\text { The presence of inappropriate } \\
\text { Phosphorus content causes off chemistry } \\
\text { in a grade of the slab }\end{array}$ & $\begin{array}{l}\text { Phosphorous content should be } \\
\text { maintained below 0.02gram/kg of steel. }\end{array}$ \\
\hline
\end{tabular}

\begin{tabular}{|c|c|c|}
\hline $\begin{array}{l}\text { CAUSES: } \\
\text { NCO/DEFECTIVE DUE } \\
\text { TO MILL PROCESS } \\
\end{array}$ & CURRENT PRACTICE & RECOMMENDED PRACTICE \\
\hline $\begin{array}{l}\text { Human Error in Cutting/ } \\
\text { Trimming of Plates } \\
\text { resulting under } \\
\text { length/width }\end{array}$ & $\begin{array}{l}\text { A calculated setpoint is fed } \\
\text { manually by operators } \\
\text { during the operation. }\end{array}$ & $\begin{array}{l}\text { SOP to be followed with parameters and set- } \\
\text { points cross verified with a rolling plan }\end{array}$ \\
\hline $\begin{array}{l}\text { Wrong tolerance of } \\
\text { thickness resulting under } \\
\text { length }\end{array}$ & $\begin{array}{l}\text { The tolerance limit is fed } \\
\text { manually during the process. } \\
\text { The tolerance limit becomes } \\
\text { wrong sometimes due to } \\
\text { human error. }\end{array}$ & $\begin{array}{l}\text { Proper SOP to be followed with parameters } \\
\text { and set-points cross verified with a rolling } \\
\text { plan }\end{array}$ \\
\hline $\begin{array}{l}\text { Formation of burr due to } \\
\text { improper Rolling }\end{array}$ & $\begin{array}{l}\text { Burr is formed due to the } \\
\text { temperature difference } \\
\text { between both sides of the } \\
\text { plate. }\end{array}$ & $\begin{array}{l}\text { SOP for controlling SKI control to be } \\
\text { followed and operated to control both sides of } \\
\text { the plate's speed to make the temperature } \\
\text { uniform across the plate }\end{array}$ \\
\hline \multirow[t]{2}{*}{$\begin{array}{l}\text { Waviness due to uneven } \\
\text { cooling and roll gap }\end{array}$} & $\begin{array}{l}\text { Uneven cooling at mulpic } \\
\text { often results in waviness. }\end{array}$ & $\begin{array}{l}\text { Uniform mulpic cooling should be ensured by } \\
\text { the plate mill process }\end{array}$ \\
\hline & $\begin{array}{l}\text { An uneven roll gap between } \\
\text { the rollers sometimes causes } \\
\text { waviness in the plate }\end{array}$ & $\begin{array}{l}\text { The uniform Roll gap should be taken care of } \\
\text { by the maintenance team during idle time. } \\
\text { Roll gap checking schedule should be } \\
\text { followed in each shift during the idle } \\
\text { condition }\end{array}$ \\
\hline $\begin{array}{l}\text { Rolled in pit, scales or } \\
\text { foreign materials }\end{array}$ & $\begin{array}{l}\text { There is no proper inspection } \\
\text { of the rolling bed during idle } \\
\text { time }\end{array}$ & $\begin{array}{l}\text { A schedule for inspection of the rolling bed } \\
\text { should be made and followed before each } \\
\text { rolling. } \\
\text { Thorough checking of the foreign materials on } \\
\text { the working platform need to be done during } \\
\text { the idle time between rolling }\end{array}$ \\
\hline
\end{tabular}

\begin{tabular}{|l|l|l|}
\hline $\begin{array}{l}\text { CAUSES: PROJECTION/ } \\
\text { MADE-TO-STOCK }\end{array}$ & CURRENT PRACTICE & RECOMMENDED PRACTICE \\
\hline $\begin{array}{l}\text { Excess Slabs are rolled, and } \\
\text { plates made to Stock for the } \\
\text { future (Projection) }\end{array}$ & $\begin{array}{l}\text { Excess slabs generated, i.e. } \\
\text { No plan slabs are rolled to } \\
\text { make plates and stored as } \\
\text { Stock for future orders. }\end{array}$ & $\begin{array}{l}\text { The marketing team has to actively search for } \\
\text { orders as per projection stock from the day of } \\
\text { rolling. Auction bidding can be done to sell the } \\
\text { made to stock plates }\end{array}$ \\
\hline
\end{tabular}




\begin{tabular}{|c|c|c|}
\hline $\begin{array}{l}\text { CAUSES: EXCESS SLAB } \\
\text { GENERATION }\end{array}$ & CURRENT PRACTICE & RECOMMENDED PRACTICE \\
\hline \multirow[t]{2}{*}{$\begin{array}{l}\text { NCO/Defective slab due to off } \\
\text { chemistry }\end{array}$} & $\begin{array}{l}\text { The presence of incompatible } \\
\text { Phosphorus content causes off } \\
\text { chemistry in a grade of the slab }\end{array}$ & $\begin{array}{l}\text { Phosphorous content should be } \\
\text { maintained below } 0.02 \mathrm{gram} / \mathrm{kg} \text { of steel. }\end{array}$ \\
\hline & $\begin{array}{l}\text { Grade mismatch due to either wrong } \\
\text { planning of slab or bad grade against } \\
\text { the planned order. }\end{array}$ & $\begin{array}{l}\text { Coordination between the Production } \\
\text { planning, LRF and VD departments }\end{array}$ \\
\hline \multirow[t]{2}{*}{$\begin{array}{l}\text { Excess slab generation due to } \\
\text { less plan quantity }\end{array}$} & \multirow{2}{*}{$\begin{array}{l}\text { When the order quantity is less than } \\
\text { average heat-size, the excess slab is } \\
\text { produced, which adds to no plan slab. }\end{array}$} & $\begin{array}{l}\text { Processing of order as per the heat-size } \\
\text { and clubbing of order if possible }\end{array}$ \\
\hline & & $\begin{array}{l}\text { The marketing team has to look for the } \\
\text { plate orders with specifications } \\
\text { matching with the excess generated slab } \\
\text { with immediate effect }\end{array}$ \\
\hline $\begin{array}{l}\text { Excess slab generation due to } \\
\text { high average heat }\end{array}$ & $\begin{array}{l}\text { If there are different grades during } \\
\text { continuous casting, then either of the } \\
\text { grades is cast more than requirement } \\
\text { causing excess slab generation. }\end{array}$ & $\begin{array}{l}\text { LRF operation has to take care during } \\
\text { the continuous casting process. }\end{array}$ \\
\hline
\end{tabular}

\begin{tabular}{|l|l|l|}
\hline $\begin{array}{l}\text { CAUSES: MILL } \\
\text { DIVERSION }\end{array}$ & CURRENT PRACTICE & RECOMMENDED PRACTICE \\
\hline Power Failure & $\begin{array}{l}\text { Power failure stops the rolling at any } \\
\text { point, and the plate is diverted from the } \\
\text { mill. }\end{array}$ & $\begin{array}{l}\text { UPS supply and DG supply to critical } \\
\text { equipment as per load capacity }\end{array}$ \\
\hline Hydraulic Failure & $\begin{array}{l}\text { Hydraulic operated equipment } \\
\text { sometimes fails during the process, } \\
\text { stopping the rolling at any point, and } \\
\text { the plate is diverted from the mill. }\end{array}$ & $\begin{array}{l}\text { Regular maintenance of the hydraulic } \\
\text { system and identifying the root cause } \\
\text { Implementation of TPM in such } \\
\text { equipment's }\end{array}$ \\
\hline $\begin{array}{l}\text { Holding a rolling due to } \\
\text { an emergency order }\end{array}$ & $\begin{array}{l}\text { Sometimes, due to critical orders, the } \\
\text { normal scheduled rolling is hold and } \\
\text { diverted from the mill. }\end{array}$ & $\begin{array}{l}\text { Rolling decisions should be taken by } \\
\text { involving higher management. }\end{array}$ \\
\hline
\end{tabular}

\begin{tabular}{|l|l|l|}
\hline $\begin{array}{l}\text { CAUSES: EXCESS } \\
\text { ROLLING OF PLATES }\end{array}$ & CURRENT PRACTICE & RECOMMENDED PRACTICE \\
\hline $\begin{array}{l}\text { Balance to Role file not } \\
\text { updated as per the rolling } \\
\text { schedule plan and multiple } \\
\text { rolling occurs for a single } \\
\text { order }\end{array}$ & $\begin{array}{l}\text { Sometimes, the balance to roll file is } \\
\text { not updated after the scheduling of a } \\
\text { rolling plan. This results in multiple } \\
\text { rolling for a single order. }\end{array}$ & $\begin{array}{l}\text { The manual operation needs to be more } \\
\text { accurate and error-free. } \\
\text { Implementation of Manufacturing } \\
\text { Execution System (MES) }\end{array}$ \\
\hline Human error in planning & $\begin{array}{l}\text { Error due to manual operation while } \\
\text { entering the orders for planning. }\end{array}$ & $\begin{array}{l}\text { Orders in ERPs should be entered as per } \\
\text { the details in the Excel tool. }\end{array}$ \\
\hline $\begin{array}{l}\text { Excess plate generation } \\
\text { after Minimum order } \\
\text { quantity }\end{array}$ & $\begin{array}{l}\text { Currently, a slab of thickness } 200 \mathrm{~mm} \\
\text { is used for } 8 \mathrm{~mm} \text { and } 10 \mathrm{~mm} \text { thickness } \\
\text { plates. }\end{array}$ & $\begin{array}{l}\text { The slab of thickness } 200 \mathrm{~mm} \text { can be used } \\
\text { to make plates of thickness up to 40mm to } \\
\text { reduce excess generation after minimum } \\
\text { order quantity. }\end{array}$ \\
\cline { 2 - 3 } & $\begin{array}{l}\text { A slab with a thickness of } 200 \mathrm{~mm}, \\
260 \mathrm{~mm} \text { and } 300 \mathrm{~mm} \text { is currently } \\
\text { used for making plates from the } \\
\text { thickness of } 8 \mathrm{~mm} \text { to } 80 \mathrm{~mm} .\end{array}$ & $\begin{array}{l}\text { Slabs with } 300 \text { mm thickness can solve } \\
\text { the purpose of 260 mm thick slabs. So, } \\
\text { slabs with a thickness of 200 - 300 mm } \\
\text { can be made only, and it will reduce the } \\
\text { excess generation of slabs and excess } \\
\text { generation of plates after minimum order } \\
\text { quantity. }\end{array}$ \\
\hline
\end{tabular}




\begin{tabular}{|l|l|l|}
\hline $\begin{array}{l}\text { CAUSES: PSFS-SALES } \\
\text { ORDER CLOSED }\end{array}$ & CURRENT PRACTICE & RECOMMENDED PRACTICE \\
\hline $\begin{array}{l}\text { Sales Order closed by the } \\
\text { Sales \& Marketing } \\
\text { department after planning } \\
\text { due to improper } \\
\text { coordination between the } \\
\text { departments. }\end{array}$ & $\begin{array}{l}\text { Orders are received from customers } \\
\text { without any advance payment. }\end{array}$ & $\begin{array}{l}\text { Advance payment (20-30 percent) from } \\
\text { customers after receiving the order. }\end{array}$ \\
\cline { 2 - 3 } & $\begin{array}{l}\text { The sales team sometimes cancels the } \\
\text { order after planning the order or } \\
\text { Rolling the order. }\end{array}$ & $\begin{array}{l}\text { The sales team should ensure the order's non- } \\
\text { cancellation after planning is given to the } \\
\text { process and fund released by finance. }\end{array}$ \\
\cline { 2 - 3 } & $\begin{array}{l}\text { The rolling schedule made by the } \\
\text { planning department is not available } \\
\text { with the sales department before } \\
\text { rolling. The rolling details are } \\
\text { circulated to the sales department } \\
\text { after rolling or then the next day. }\end{array}$ & $\begin{array}{l}\text { Casting \& rolling plan should be available } \\
\text { with the sales department also. } \\
\text { Proper coordination between the planning } \\
\text { team, sales team and production team is } \\
\text { required-implementation of MES system to } \\
\text { coordinate the functioning of the associated } \\
\text { departments. }\end{array}$ \\
\hline
\end{tabular}

\begin{tabular}{|l|l|l|}
\hline CAUSES: LETTER OF & CURRENT PRACTICE & RECOMMENDED PRACTICE \\
\hline $\begin{array}{l}\text { Production delay for } \\
\text { Plate dispatch within }\end{array}$ & $\begin{array}{l}\text { Plates are produced if the rolling plan is } \\
\text { given to the production team. There is no } \\
\text { cross-check with the marketing department } \\
\text { for the LC date. }\end{array}$ & $\begin{array}{l}\text { The production should be held till the LC } \\
\text { amendment/extension if it is expected that } \\
\text { production will not be completed within } \\
\text { the LC period. }\end{array}$ \\
\cline { 2 - 3 } & $\begin{array}{l}\text { LC period is fixed with the customer without } \\
\text { considering any process constraints for any } \\
\text { specific grades. LC period is randomly fixed } \\
\text { with the customers. So, the production of } \\
\text { critical grades may exceed the LC period. }\end{array}$ & $\begin{array}{l}\text { A proper negotiation by the marketing } \\
\text { team required to fix the LC period }\end{array}$ \\
\hline $\begin{array}{l}\text { Unavailability of } \\
\text { vehicles or any other } \\
\text { logistics issues within } \\
\text { the LC period }\end{array}$ & $\begin{array}{l}\text { Sometimes the plates cannot be dispatched } \\
\text { within the LC period due to logistics issues } \\
\text { like unavailability of vehicles for road } \\
\text { transport or some other reason related to } \\
\text { logistics. }\end{array}$ & $\begin{array}{l}\text { Production planning should add some } \\
\text { buffer time to total production time, } \\
\text { considering the uncertainty of logistics. }\end{array}$ \\
\cline { 2 - 3 } & $\begin{array}{l}\text { Proper coordination between the } \\
\text { production and logistics team is required, } \\
\text { and the logistics team should plan for } \\
\text { dispatch from the day of the rolling plan. }\end{array}$ \\
\hline
\end{tabular}

\section{About Our Authors}

Saroj Koul [Orcid ID: 0000-0002-3051-5625] is a Professor of Supply Chain Management at the Jindal Global Business School, India. Her research focuses on system dynamics models, supply chain management, SMEs and organizational communication.

Pratyush Samantaray MBA, has around ten years of experience in the steel manufacturing industry. His current research interest includes quality management and process control of mid-sized steel companies.

Atul V MBA, is presently employed as Assistant Vice President, Sales \& Marketing at SMS India Pvt Ltd., India (SMS group GmbH, Germany). His industry experience spans 25 years, during which he has been associated with the installation, operation and maintenance of iron and steel making plant and establishing such facilities. 